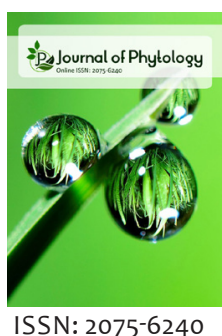

ISSN: $2075-6240$

Received: March 13, 2019 Accepted: May 30, 2019 Published: June 06, 2019

*Corresponding author: K. Raja

Email: kraja_sst@rediffmail.com

\section{Physiological and biochemical changes in desiccation sensitive curry leaf (Murraya koenigii (L.) Sprengel) seeds}

\author{
K. Arulmoorthy', K. Raja*, S. Sundareswaran² \\ 'Department of Seed Science and Technology, Tamil Nadu Agricultural University, Coimbatore - 641003 , \\ Tamil Nadu, India, ${ }^{2}$ Seed Centre, Tamil Nadu Agricultural University, Coimbatore - 641 003, Tamil Nadu, India.
}

\begin{abstract}
Curry leaf (Murraya koenigii (L.) Sprengel) is an important spice tree propagated by seeds. However, the seeds are sensitive to desiccation and considered as recalcitrant. Therefore, an experiment was conducted to analyze its level of desiccation and changes takes place during water loss. The results indicated that the reduction in seed moisture from 47.4 per cent leads to loss in viability. In which, the initial seed germination $(100 \%)$ declines slowly during desiccation and at the seed moisture content of 33.1 per cent it recorded 69 per cent germination at six days of exposure under ambient temperature $\left(30 \pm 2^{\circ} \mathrm{C}\right)$. Further moisture loss leads to drastic reduction in germination and hence, this could be the critical or lowest safe moisture content. In addition, the reduction in seedling vigour and enzymatic activity and increase in seed leachate were noticed during desiccation of the curry leaf seeds.
\end{abstract}

KEYWORDS: Curry leaf, critical or lowest safe moisture content, recalcitrant seed, desiccation sensitive

\section{INTRODUCTION}

Curry leaf (Murraya koenigii (L.) Sprengel) is an important leafy vegetable cum spice species belongs to the family Rutaceae. It is originated in India and spread by Indian migrants to Sri Lanka, Bangladesh, Malaysia, Pakistan, South Africa and Reunion Islands. The trees are small spreading shrub and the leaves are the major economic part. The leaves are used at very small quantities to make distinct aroma in Indian dishes. The leaves are also contains certain amount of volatile oil and glycoside called "Koenin" which has the good digestive property in human system. Therefore, the leaves are being used in many Indian ayurvedic and unani medicines [1].

Curry leaf is mainly propagated through seeds and it has polyembryonic nature [2]. However, the seeds should be sown immediately after collection because of short viability [3]. Also, the storage of seeds is difficult for longer period. Therefore, the present study was contemplated to assess the Critical Moisture Content (CMC) or Lowest Safe Moisture Content (LSMC) for maintaining the seed viability and vigour. In addition, the physiological and biochemical changes takes place during desiccation was considered in the study.

\section{MATERIALS AND METHODS}

The fully ripened fruits were collected and the seeds were extracted manually. Then, the seeds were uniformly graded and treated with carbendazim fungicide. The seeds were spread in the trays in a thin layer and placed at ambient condition $\left(30 \pm 2^{\circ} \mathrm{C}\right)$ for desiccation. Similarly, the fruits were also placed for desiccation. Then, the fruit and seed samples were taken at once in two days interval for assessing the moisture content, physiological and biochemical changes takes place in the seed during desiccation. The fruit and seed moisture content were determined by hot air oven method at $105^{\circ} \mathrm{C}$ for $16 \pm 1 \mathrm{~h}$. Germination test was conducted in four replications with 100 seeds each in sterilized sand medium [4] and the final evaluation was done at 50 days after sowing. Speed of germination was calculated by using the formula [5], $\mathrm{X}_{1} / \mathrm{Y}_{1}+\mathrm{X}_{2}-\mathrm{X}_{1} \mathrm{Y}_{2}+\ldots \ldots .+$ $\mathrm{X}_{\mathrm{n}}\left(\mathrm{X}_{\mathrm{n}-\mathrm{l}}\right) / Y_{\mathrm{n}}$, where, $\mathrm{X}_{\mathrm{n}}-$ number of seeds germinated at $\mathrm{n}^{\text {th }}$ count, $\mathrm{Y}_{\mathrm{n}}$ - number of days from sowing on $\mathrm{n}^{\text {th }}$ count. Seedling length was measured in randomly selected ten seedlings during the evaluation of the germination test. Also, the vigour index was calculated by multiplying the germination percentage and seedling length [6].

Electrical conductivity of seed leachate was measured in the seeds placed for desiccation [7] and free sugar of such 
leachate was also determined [8]. In addition, the seed chlorophyll content was measured at $652 \mathrm{~nm}$ using UV-VIS spectrophotometer [9]. Alpha-amylase [10] enzyme activity and total phenol content [11] of the seeds were analyzed at 620 and $650 \mathrm{~nm}$ respectively, using UV-VIS spectrophotometer.

\section{STATISTICAL ANALYSIS}

The data collected were subjected to statistical analysis [12] and the critical difference values were calculated at $5 \%$ probability level.

\section{RESULTS AND DISCUSSION}

In general, the seeds are classified as 'orthodox' and 'recalcitrant' based on the storage behavior. In which, the orthodox seeds can tolerate the desiccation temperature and recalcitrant are sensitive to that. However, the degree of sensitivity varies with species [13]. Usually, the recalcitrant seeds contain high moisture content which is mainly because of their inhabitant in humid regions. Also, the seeds are shed from mother plant with high moisture content of 30 to 70 percent [14]. Likewise, the results of the present study in curry leaf showed that the freshly collected fruits and seeds had high moisture content (55.3 and 47.4\%). However, the reduction in moisture content was noticed when it was stored under ambient condition $\left(30 \pm 2^{\circ} \mathrm{C}\right)$. Similarly, the seed germination was declined gradually from 100 to 69 per cent at six days after desiccation with the reduction in seed moisture content of 33.1 per cent. Thereafter, a certain reduction in germination (23\%) was noticed at 27.6 per cent moisture content of the seed. Subsequently, the germination was reduced greatly and recorded nil germination at 15.9 per cent moisture content. Therefore, it could be confirm that the curry leaf possess the desiccation tolerance up to the seed moisture content of 33.1 per cent and said to be critical level for the maintenance of seed viability. The reduction in fruit and seed weight was also observed due to loss in moisture content (Table 1). Similar, results of viability reduction was reported by the scientists in many recalcitrant species. For example, the critical moisture content (CMC) for various crops viz., rubber (25\%) [15], jack (39\%) [16], avocado (49\%) [17], arecanut (32.8\%) [18], cocoa (22.0\%) [19], nutmeg (34\%) [20] and Opilia amentacea (15-19\%) [21] was found earlier. Nevertheless, the critical moisture content also called as 'Lowest Safe Moisture Content (LSMC)' [22]. The CMC was inconsistent in Shorea chinensis seed in different drying regimes and the seed lasts its viability completely when they were dried to 46 per cent moisture content and the scientists identified this as 'Lethal Moisture Content' [23].

Also, the desiccation tolerance in recalcitrant or intermediate seeds is depends on drying rate and the slow drying gives more tolerance than rapid drying [24]. Fosbergiam shweliensis seeds act as partly desiccation-tolerant i.e., intermediate in storage behaviour [25]. In case of Gymnacranthera canarica, the seeds showed recalcitrant behaviour and can be stored up to two and half months in laboratory conditions [26-28]. Similarly, the present study indicated that the initial speed of germination (1.18), seedling length $(21.9 \mathrm{~cm})$, seedling dry matter $(0.61 \mathrm{~g} / 10$ seedlings) and vigour index (2197) were reduced during desiccation. Nevertheless, the least speed of germination $(0.02)$, seedling length $(6.7 \mathrm{~cm})$, seedling dry matter $(0.01 \mathrm{~g} / 10$ seedlings $)$ and vigour index (14) were recorded on $12^{\text {th }}$ day of desiccation up to which the seeds showed viability (Figure $1 \& 2$ ). Reduction in seedling vigour might be due to the desiccation effect in the seed which particularly causes the damage to the cellular organelles. In addition to curry leaf, such reduction in seedling vigour with desiccation was recorded in many crops like rubber [15], jack [16], avocado [17] and arecanut [18]. The seed vigour was higher during early stages of harvest in litchi and longan seeds [29] as recorded in curry leaf.

The leachate electrical conductivity, free sugar, seed chlorophyll, $\alpha$-amylase and total phenol contents were also observed during

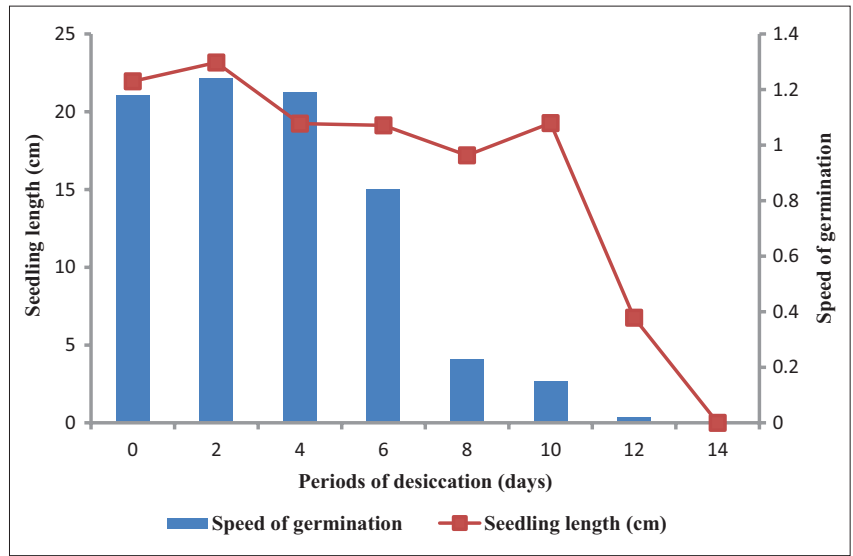

Figure 1: Effect of desiccation on seed vigour and seedling length in curry leaf

Table 1: Effect of desiccation on seed traits and viability in curry leaf

\begin{tabular}{|c|c|c|c|c|c|}
\hline Desiccation (Days) & Fruit weight (g) & Seed weight (g) & Fruit moisture (\%) & Seed moisture (\%) & Germination (\%) \\
\hline 0 & 3.89 & 1.69 & 55.3 & 47.4 & $100(87.1)$ \\
\hline 2 & 3.80 & 1.49 & 49.4 & 42.1 & $100(87.1)$ \\
\hline 4 & 3.23 & 1.37 & 45.1 & 38.2 & $94(75.8)$ \\
\hline 6 & 2.68 & 1.12 & 42.4 & 33.1 & $69(56.2)$ \\
\hline 8 & 2.54 & 1.05 & 37.3 & 27.6 & $23(28.7)$ \\
\hline 10 & 2.34 & 0.99 & 32.6 & 23.4 & $14(21.9)$ \\
\hline 12 & 2.32 & 0.88 & 28.2 & 18.3 & $2(8.1)$ \\
\hline 14 & 2.30 & 0.80 & 22.6 & 15.9 & $0(2.8)$ \\
\hline SEd & 0.18 & 0.08 & 0.72 & 0.40 & 7.6 \\
\hline$C D(P=0.05)$ & 0.37 & 0.18 & 1.50 & 0.84 & 15.7 \\
\hline
\end{tabular}

(Values in parenthesis indicate the arc sine transformed values) 
desiccation of curry leaf seeds which showed significant differences in fresh and desiccated seeds. It was noticed that the loss of seed moisture leads to increase in solute leakage in which the freshly collected seeds have showed the minimum solute leakage $\left(77.6 \mu \mathrm{Sm}^{-1}\right)$ while, it was increased $\left(499.7 \mu \mathrm{Sm}^{-1}\right)$ at the $14^{\text {th }}$ day of desiccation (Table 2). Also, the leachate free sugars were showed the increasing trend from 0.81 to $2.71 \mathrm{mg}$ seed $^{-1}$ during desiccation of the seeds (Table 2). Usually, the curry leaf seed possess the chlorophyll pigment which ultimately gives green colour to the seed. However, the seed chlorophyll content gets decreased from 1.08 to $0.35 \mathrm{mg} \mathrm{g}^{-1}$ of seed at $14^{\text {th }}$ day of

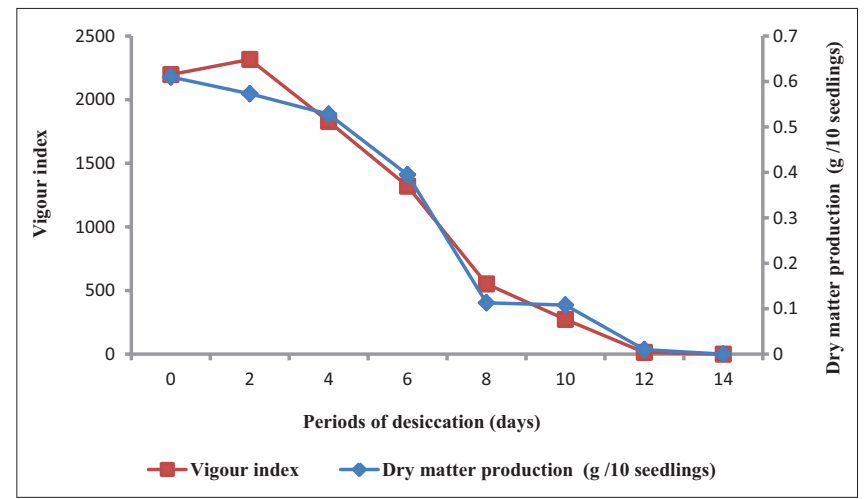

Figure 2: Effect of desiccation on seedling vigour in curry leaf

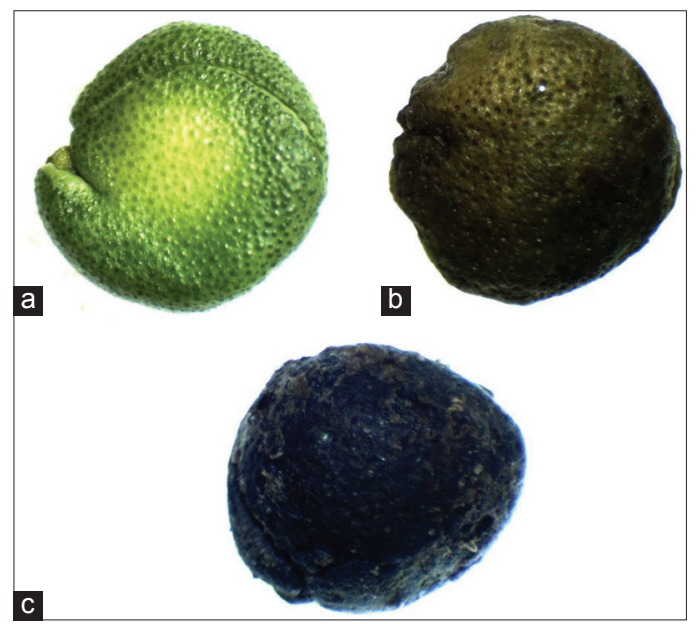

Figure 3: Effect of desiccation on changes in seed morphological traits in curry leaf. a. Fresh seed (viable); b. 15 days after desiccation (non-viable); c. 30 days after desiccation (non-viable) desiccation (Table 2). Therefore, the seed colour becomes brown or black at $30^{\text {th }}$ day of desiccation (Figure 3 ) and indicates the death of the seed. In addition, the $\alpha$-amylase enzyme activity was also reduced in desiccating seed in which it was higher in fresh seed (10.75 $\mathrm{mg} \mathrm{g}^{-1}$ of seed) and tends to decrease rapidly (6.24 $\mathrm{mg} \mathrm{g}^{-1}$ of seed) during desiccation storage (Table 2). The total phenol content was also showed decreasing trend in curry leaf seed during desiccation in which, it declined from 8.96 to $6.28 \mu \mathrm{g} \mathrm{g}^{-1}$ of seed (Table 2). Similar to curry leaf, increased seed leachate contents due to desiccation were reported earlier in arecanut [18]. Cell membrane instability leads the electrolyte leakage [30, 31]. During desiccation, reduction in phenol content was noticed in arecanut seeds also [18]. Similar reports on loss of membrane integrity leads to efflux of cellular constituents like sugar, amino acid, phenol and phosphates were reported earlier [32]. Also, reduction in amylolytic enzyme activity during desiccation seeds was reported earlier [33-35].

Similarly, Pammenter and Berjak [36] opined that the damage of recalcitrant seeds were due to absence or incomplete expression of physical characteristics of cells and intracellular constituents, metabolic 'switching off' and 'switching on' mechanism, together with antioxidant systems, the presence and operation of repair systems. Similarly, scientists suggested the possible reasons for fall in viability of recalcitrant cocoa seeds [37]. The deteriorated seeds produced larger quantities of volatile growth inhibitory substances during germination [38] and the compounds include isovaleraldehyde, isobutyraldehyde, propionaldehyde, methanol, acetaldehyde, methyl acetate, diacetyl etc. [39].

\section{CONCLUSION}

Therefore, it is concluded that the freshly harvested curry leaf possess the high seed moisture content of about 47.4 per cent. However, the reduction in seed moisture content was recorded along with the loss in seed viability during storage. Therefore, the critical moisture content or lowest safe moisture content for curry leaf seed has been fixed as 33.1 per cent below which rapid reduction in viability was recorded. Also, the reduction in speed of germination and seedling vigour were recorded due to loss of seed moisture. Increased electrical conductivity and free sugars in seed leachate were also observed. Desiccation effect also caused the reduction in phenol, chlorophyll and $\alpha$-amylase activity in the seed. Therefore, it is important to store the curry leaf seed without much loss of moisture from the seed.

Table 2: Effect of desiccation on biochemical changes in curry leaf seed

\begin{tabular}{|c|c|c|c|c|c|}
\hline Desiccation (Days) & Electrical conductivity $\left(\mu \mathrm{Sm}^{-1}\right)$ & $\begin{array}{c}\text { Free sugars } \\
\text { ( } \mathrm{mg} \mathrm{g}^{-1} \text { of seed) }\end{array}$ & $\begin{array}{l}\text { Total phenols } \\
\left(\mu \mathrm{g} \mathrm{g}^{-1} \text { of seed) }\right.\end{array}$ & Seed chlorophyll ( $\mathrm{mg} \mathrm{g}^{-1}$ of seed) & $\begin{array}{c}\boldsymbol{\alpha} \text {-amylase } \\
\text { (mg g-1 of seed) }\end{array}$ \\
\hline 0 & 77.6 & 0.81 & 8.96 & 1.08 & 10.75 \\
\hline 2 & 138.0 & 0.93 & 8.82 & 0.72 & 9.90 \\
\hline 4 & 202.0 & 0.97 & 7.51 & 0.49 & 9.58 \\
\hline 6 & 223.9 & 1.42 & 7.19 & 0.48 & 9.20 \\
\hline 8 & 286.4 & 1.63 & 6.74 & 0.42 & 8.76 \\
\hline 10 & 318.1 & 1.82 & 6.56 & 0.38 & 7.01 \\
\hline 12 & 495.3 & 1.91 & 6.52 & 0.37 & 6.32 \\
\hline 14 & 499.7 & 2.71 & 6.28 & 0.35 & 6.24 \\
\hline SEd & 70.4 & 0.01 & 0.08 & 0.007 & 0.07 \\
\hline$C D(P=0.05)$ & 145.4 & 0.03 & 0.18 & 0.014 & 0.15 \\
\hline
\end{tabular}




\section{AUTHOR'S CONTRIBUTIONS}

All the authors are contributed equally in the experiment. In which, first author K. Arulmoorthy has carried out the experiment and interpreted the data. Next author, K. Raja has designed the experiment, guided and validated the manuscript. Similarly, S. Sundareswaran participated in the review of the manuscript.

\section{REFERENCES}

1. Singh, S., More, P. K., \& Mohan, S. M. Curry leaves (Murraya koenigii Linn. Sprengal) -a miracle plant. Indian J. Sci. Res, 2014; 4(1): 46-52.

2. Sivasubramaniam, K. and Selvarani, K. Studies on curry leaf (Murrya koenigii) seeds. Current Science, 2012; 103:883-885.

3. Raja, K., Palanisamy, V. and Selvaraju, P. Desiccation sensitivity of recalcitrant curry leaf (Murraya koenigii (Linn.) Sprengel) seeds. IPGRI/ Danida Forest Seed Centre (Denmark) Newsletter, 2001; 9:27-29.

4. ISTA, 2011. International rules for seed testing. International Seed Testing Association, Zurich, Switzerland

5. Maguire, J.D. Speed of germination-Aid in selection and evaluation of seedling emergence and vigour. Crop Sci., 1962; 2: 176-177.

6. Abdul-Baki, A.A. and Anderson, J.D. Vigour determination in soya bean by multiple criteria. Crop Sci., 1973; 13: 630-633.

7. Presley, J.T. Relation to protoplast permeability of cotton seed viability and predisposition of seedling diseases. Plant Disease Reporter, 1958; $42: 582$.

8. Somogyi, M. Note on sugar deterioration.J. Biol. Chem. 1952; 195: 19-23.

9. Yoshida, S, Forno, D. A. and Cock, J. H. Laboratory Manual for Physiological Studies of Rice. IRRI Publication, Philippines, 1971: Pp36-37.

10. Paul, A.K., Mukherji, S. and Sircar, S.M. Metabolic changes in rice seeds during storage. Indian J. Agri. Sci., 1970; 40: 1031-1036.

11. Malik, C.P. and Singh, M.B. In: Plant Enzymology and Histoenzymology. Kalyani Publishers, New Delhi, 1980:Pp. 53.

12. Panse, V.G. and Sukhatme, P.V. Statistical methods of agricultural workers. ICAR, Pub., New Delhi, 1967.

13. Roberts, E.H. Predicting the Storage Life of Seeds. Seed Sci. \&Technol., 1973; 1: 499-514.

14. Chin H.F., Hor, Y.L and Mohd.Lassim, M.B. Identification of recalcitrant seeds. Seed Sci. \&Technol., 1984; 12:429-436

15. Gunasekaran, M. and Krishnasamy, V. Retention of vigour and viability of rubber (Hevea brasiliensis muell-Arg.) seeds. Neo Botanica, 1998; 6: 47-53.

16. ShyllaMerlin, J. and Palanisamy, V. Seed viability and storability of jack fruit (Artocarpus heterophyllus L.). Seed Res., 2000; 28: 166-170.

17. Raja, K., Palanisamy, V. Selvaraju, P. and Shanmugasundaram, K.A. Desiccation sensitivity of avocado (Persea americana Mill.) seeds. IPGRI/Danida Forest Seed Centre (Denmark) Newsletter, 2001; 8: 22-24.

18. Raja, K., Palanisamy, V. and Selvaraju, P. Deteriorative changes associated with the loss of viability in desiccation - sensitive arecanut (Areca catechu L.) seed. Seed Sci. \& Technol., 2005; 33: 177-184.

19. Vanitha, C., Ramamoorthy, K., Vijayakumar,A. and Sivasubramaniam, K. Moist sand conditioning to minimize the loss of viability in cocoa (Theobroma cacao Linn.) seed. Green page, 2005; 4:487-491.

20. Sivakumar, V., Warrier, R.R, Anandalakshmi, R., Tigabu, M., Odén, P.C., Vijayachandran, S.N., Geetha, S. and Singh, B.G. Germination requirements and storage behavior of Myristica dactyloides Gaertn seeds. Seed Sci. \&Technol., 2006; 34:729-733.

21. Daboue, E.M.S, Neya, O., Nandziga, E.B., Ouedraogo, A. Ouedraogo, M. and Pasquini, S. Morphometric characteristics and desiccation response of Opilia amentacea seeds from Burkina Faso. Seed Sci. \& Technol., 2017; 45: 354-367.

22. Tompsett, P.B. Desiccation and storage studies on Dipterocarpus robur L. seeds. Ann. Appl. Bio, 1987; 110:371-379.

23. Yan, X. F., Cao, M. and H.L. Xu. Effects of desiccation and temperature on the germination of Shorea chinensis (Dipterocarpaceae) seeds. Seed Sci. \& Technol., 2007; 5:232-236.

24. Xue, Peng and Wen, Bin. Desiccation tolerance of intermediate pomelo (Citrus maxima 'Mansailong') seeds following rapid and slow drying. Seed Sci. \& Technol., 2018; 46: 511-519.

25. Li, A.H., Yang, J., He, H.J., Yang, X.Y. Seed desiccation tolerance and germination of a potentially threatened Chinese species Fosbergia shweliensis. Seed Sci. \&Technol., 2013; 41: 479-482.

26. Keshavachandra, K. and Krishnakumar, G. Seed germination studies on Gymnacranthera canarica (King) Warb - A Vulnerable tree species of a highly threatened Myristica swamp ecosystem. J. Threatened Taxa, 2016; 8: 9009-9013.

27. Ellis, R.H., and Roberts, E.H. Towards a rational basis for testing seed quality. In: Seed Production (Ed.P.D. Hebblethwaite).Butter Worths, London, 1980, 605-635.

28. Pritchard, H.W., Haye, A. J., Wright, W. J. and Steadman,K.J., A comparative study of viability Inga species desiccation relation to the physical characteristics and chemical composition of the embryo. Seed Sci. \&Technol., 1995; 23: 85-100.

29. Xia, Q.H, Chen, R.A and Fu, J.R. Effects of desiccation, temperature and other factors on the germination lychee (Litchi chinensis Sonn. and longan (Euphoria longan Stend.) seeds. Seed Sci. \&Technol. 1992; 20:119-127

30. Heydecker, W. Vigour In: Viability of Seeds. (Ed. E.H. Roberts). Chapman and Hall, London, 1972: 209-252.

31. Loomis, W.D. and Battaile. Plant Phenol compounds and the isolation of plant enzymes. Phytochemistry, 1966; 5: 423-438.

32. Nautiyal, A.R. and Purohit,A.N., Seed viability in sal.III. Membrane distruption in ageing seeds of Shorea robusta. Seed Sci. \& Technol., 1985; 13: 69-76

33. Szezotka, Z. Amylolytic activity in acorns of Quercus borealis michx. during storage under controlled conditions. Arboretrum Hornickve,1974:19:129-134.

34. Clegg, J.S. Metabolism and the intracellular environment. The vicina water network model. In: Cell - Associated Water, (Eds: W. DrostHansen and J.S. Clegg), Academic Press, New York, 1979: Pp363-413.

35. Berjak, P., Dini,M. and Pammenter, N.W. Possible mechanisms underlying the differing dehydration responses in recalcitrant and orthodox seeds: desiccation -associated sub cellular changes in propagates of Avicenia marina. Seed Sci. \& Technol., 1984; 12: 365-384

36. Pammenter, N.W. and P. Berjak. A review of recalcitrant seed physiology in relation to desiccation - tolerance mechanisms. Seed Sci., Res., 1999; 9: 13-37.

37. Boroughs, H. and Hunter, J.R. The effect of temperature on the germination of cocoa seeds. Proc. Amer. Soc. Hort. Sci. $1963 ; 82: 222$.

38. Bhattacharyya, A.K. and Basu, R.N. Retention of vigour and viability of jack fruit (Artocarpus heterophyllus Lam.) seed. Indian Agric., 1992; 36(2):65-74.

39. Bailey, S.D., Mitchell, D.G., Bazinet, M.L. and Weurman, C.J. 1962 Studies on the volatile components of different varieties of cocoa beans. J. Food Sci., 27:165-170. 